\title{
Discontinuous hydration improves germination and drought tolerance in Annona
}

\section{squamosa seedlings}

\author{
A hidratação descontínua melhora a germinação e tolerância à seca em mudas de Annona quamosa \\ La hidratación discontinua mejora la germinación y la tolerancia a la sequía en plántulas de
}

\author{
Annona squamosa
}

Received: 03/09/2021 | Reviewed: 03/16/2021 | Accept: 03/19/2021 | Published: 03/27/2021

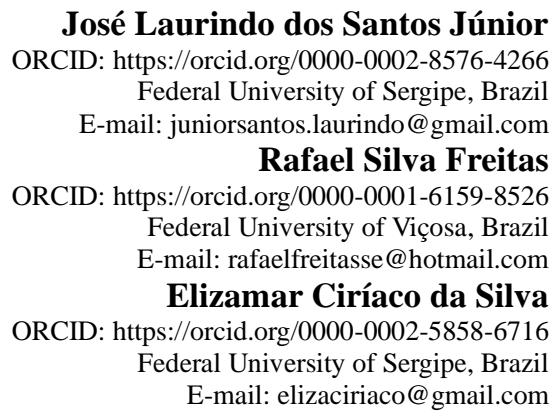

\begin{abstract}
The aim of this work was to determine if the discontinuous hydration of A. squamosa seeds benefit its seed germination and if the seedlings from these seeds have a greater tolerance to water deficit through the analysis of growth parameters. The experimental design was a completely randomized, in a $4 \times 3$ factorial, with four HD cycles in seeds (zero, one, two and three) and three water treatments (control with daily watering, and cycles of five and tenintervals days between watering). Plant height, stem diameter, number of leaves, dry biomass, root/shoot ratio, leaf area, specific leaf area, and leaf area ratio were evaluated. Discontinuous hydration treatments benefited germination and promoted a better growth of the seedlings under water deficit cycles. The application of three HD cycles increased plant height, stem diameter, number of leaves, leaf area and dry matter of the seedlings compared to the other cycles. On the other hand, water suppression caused a reduction in the growth of A. squamosa, especially at ten-day intervals between watering. HD cycles in the seeds improved drought tolerance in the seedlings, mainly when three HD cycles are applied to the seeds, suggesting this is a good technique to produce seedlings better tolerant to environments with reduced water availability.
\end{abstract}

Keywords: Sugar apple; Dry matter; Water deficit; Growth.

\section{Resumo}

O objetivo deste trabalho foi determinar se a hidratação descontínua de sementes de A. squamosa beneficia sua germinação e se as mudas oriundas dessas sementes apresentam maior tolerância ao déficit hídrico por meio da análise de parâmetros de crescimento. $\mathrm{O}$ experimento foi inteiramente casualizado, em fatorial $4 \times 3$, utilizando quatro ciclos de HD nas sementes (zero, um, dois e três) e três tratamentos hídricos (controle - rega diária, irrigação em intervalos de cinco e dez dias). Foram avaliados: altura, diâmetro do caule, número de folhas, biomassa seca, partição de biomassa seca, razão raiz/parte aérea, área foliar, área foliar específica e razão da área foliar. Os tratamentos de hidratação descontínua beneficiaram a germinação e promoveram um melhor crescimento das plântulas sob supressão hídrica. A aplicação de três ciclos de HD ampliou a altura, diâmetro do caule, número de folhas, área foliar e matéria seca das plântulas frente aos demais ciclos. A supressão hídrica de dez dias reduziu a matéria seca, a área foliar e área foliar específica. Os ciclos de HD melhoram a tolerância à seca de plântulas de A. squamosa, principalmente quando aplicado três ciclos de HD nas sementes, sugerindo-a como uma boa técnica para produzir plântulas melhor aclimatadas a áreas com baixa disponibilidade de água.

Palavras-chave: Pinha; Matéria seca; Déficit hídrico; Crescimento.

\section{Resumen}

El objetivo de este trabajo fue determinar si la hidratación discontinua de semillas de A. squamosa beneficia su germinación y si las plántulas de estas semillas son más tolerantes al déficit hídrico mediante el análisis de parámetros de crecimiento. El experimento fue completamente casual, en un factorial 4x3, utilizando cuatro ciclos de HD en las semillas (cero, uno, dos y tres) y tres tratamientos de agua (control - riego diario, riego a intervalos de cinco y diez días). Fueron evaluados: altura, diámetro del tallo, número de hojas, biomasa seca, partición de biomasa seca, relación 
raíz / porción aérea, área foliar, área foliar específica y razón área foliar. Los tratamientos de hidratación discontinua beneficiaron la germinación y promovieron un mejor crecimiento de las plántulas bajo supresión de agua. La aplicación de tres ciclos de HD aumentó la altura, diámetro del tallo, número de hojas, área foliar y materia seca de las plántulas en comparación con los otros ciclos. La supresión de agua de diez días redujo la materia seca, el área foliar y el área foliar específica. Los ciclos de HD mejoran la tolerancia a la sequía de las plántulas de A. squamosa, especialmente cuando se aplican tres ciclos de HD sobre las semillas, lo que sugiere que es una buena técnica para producir plántulas mejor aclimatadas a áreas con poca disponibilidad de agua.

Palabras clave: Anon; Materia seca; Déficit hídrico; Crecimiento.

\section{Introduction}

Drought events that occur in arid and semi-arid regions have intensified due to global warming and intermittent rainfall, which has also affected humid and urban environments (Güneralp et al., 2015; Xu et al., 2019). These events, intense and frequent, accentuate declines on growth and plant yield (Silva et al., 2013; Santos Júnior et al., 2020), with negative consequences for the agricultural sector (Li et al., 2009; Lemos et al., 2014; Güneralp et al., 2015; Ramos et al., 2016). In this perspective, family farming suffers the most from these losses (Li et al., 2009; Lemos et al., 2014; Güneralp et al., 2015; Marengo et al., 2016). Thus, for the development and permanence of agribusiness, it is necessary to adopt techniques that increase the drought tolerance in crop plants (Mahajan et al. 2011; Ramos et al., 2016; Oliveira Júnior et al., 2019).

Certainly, seed conditioning by hardening, also referred to as hydroconditioning, is a simple, safe and inexpensive option that can be used as a pre-germinative treatment (Farooq et al., 2019). This technique consists of successively alternating the hydration and dehydration of the seeds during pre-germination, until they return to their initial weight, before the radicle emission. While hydration stimulates the biochemical processes that culminate in germination, dehydration stops them (Meiado, 2013).

Regardless of the conditioning agent, this previous exposure has promoted improvements in germination parameters and plant development in several crops such as rice (Oryza sativa L.) (Jisha \& Puthur, 2016), chickpeas (Cicer arietinum L.) (Samal et al., 2019), mung bean (Vigna radiata L.) (Bhadane et al., 2019) and soursop (Annona muricata L.) (Okoli et al., 2016; Singh \& Maheswari, 2017), producing more stress-tolerant seedlings to take environmental stresses, such as water deficit (Farooq et al., 2019; Wojtyla et al., 2020) for promoting "stress memory" (Chen \& Arora, 2013).

The stress memory stores information about a stressful event during pre-germination, to, if necessary, recruit this information in the future. This recruitment allows an improved response to this future condition due to the epigenetic regulations that can generate memory stress (Chen \& Arora, 2013). Also, some works suggest that these characteristics may benefit species grown in regions with similar edaphoclimatic characteristics to the northeast of Brazil (Marengo et al., 2016).

Annona squamosa L. (Annonaceae) is a fruit species whose main producers are the states of Bahia, Alagoas, Pernambuco, Ceará and São Paulo, with Northeast Brazil holding 94\% of all cultivated areas in Brazil. Its exotic fruit is known as sugar apple, in Portuguese known as "pinha, ata or fruta do conde". In 2009, the production of this fruit averaged $5.0 \mathrm{t}$ /ha/year, around 21 thousand tons, considered low. But, in 2012, the production only in Bahia was 20.1 thousand tons (Lemos et al., 2014). Propagation occurs both sexually and asexually. However, sexual propagation faces challenges, since its seeds have morphophysiological dormancy (Sousa et al., 2008) and its seedlings are poorly tolerant to drought stress (Rodrigues et al., 2010), which requires methods that can improve the germinative performance, as well as the production of seedlings with better adaptation to the hot and dry climate, with periods of water deficit, common to northeastern Brazil (Marengo et al., 2016).

For this purpose, the aim of this work was to determine if the discontinuous hydration of $A$. squamosa seeds benefit its seed germination and if the seedlings from these seeds have a greater tolerance to water deficit through the analysis of growth parameters. 


\section{Methodology}

The present study was carried out at the agricultural greenhouse and at the Plant Physiology and Ecophysiology Laboratory of the Federal University of Sergipe (1055'32"S, 3706'08"W) in São Cristóvão, east of the state of Sergipe, Brazil, between December 2018 and April 2019. The temperature and relative humidity in the agricultural greenhouse were monitored with a thermohygrometer AK172 (AKSO) throughout the experimental period. The average temperature during the experimental period was $30.6^{\circ} \mathrm{C}$, with a minimum of $25.9^{\circ} \mathrm{C}$ and a maximum of $41.9^{\circ} \mathrm{C}$. The average relative air humidity recorded was approximately $70 \%$, with maximum and minimum values of $97.4 \%$ and $35.5 \%$, respectively.

The seeds of Sugar apple (Annona squamosa L.), from commercially obtained fruits were washed with a $2 \%$ sodium hypochlorite solution for 30 seconds and dried for 72 hours at room temperature $\left(25^{\circ} \mathrm{C}\right)$. These seeds were submitted to three hydration and dehydration times (one, two and three HD cycles) as a pre-germinative treatment, corresponding to 36 hours of hydration and 7 hours of dehydration, values obtained after plotting the hydration and drying curves, and their control as being the zero cycle, following the protocols described by Lima et al. (2018). The hydration time in distilled water was determined plotting a soaking curve, where the seeds (eight replications of 25 seeds each, $n=200$ ) were weighed and placed in petri dishes containing filter paper moistened with distilled water. We weighed the plates at hourly intervals and after that, the hydration time was determined, being $1 / 2$ of the time the greatest water absorption in phase I of the three-phase pattern of water absorption by the seeds, called time X (Lima et al., 2018). On the other hand, the time of dehydration in a laboratory environment $\left(25^{\circ} \mathrm{C}\right)$, was obtained by weighing at intervals of 1 hour, it was determined as the time necessary for the seeds (eight replications of 25 seeds each, $n=200$ ) hydrated in time $X$ to return to the initial weight, being, respectively, 36 hours of hydration and 7 hours of dehydration.

After determining the hydration and dehydration times and applying the HD cycles, four replications of 25 seeds per pre-germ treatment of HD cycle were placed to germinate in trays containing sand washed in an agricultural greenhouse. These trays were watered daily and the seed germination monitored for 45 days; the seedling emergence was the criterion we used to consider a seed as germinated. From these data, we calculated each discontinuous hydration treatment germinability (\%G), emergence rate index (ERI), mean germination time (MGT), and synchrony (Z) of seed germination.

After emergence, we transplanted the seedlings to polyethylene bags with a capacity of $2 \mathrm{~kg}$ containing as substrate a mixture of vegetal soil, bovine manure and washed sand (3: 1: 1, v/v). They were watered daily close to the field capacity ( $12 \%$ of the volumetric moisture of the soil) during the acclimatization period (one month) that preceded the differentiation of water treatments.

Subsequently, the seedlings were subjected to intermittent drought by irrigation suspension cycles. The experimental design was entirely randomized in a $4 \times 3$ factorial design, corresponding to four pre-germinative treatments on the seeds (zero as control, one, two and three cycles of HD as conditioning) and three water treatments [daily watering as control, and intervals of five (moderate water deficit) and ten (severe water deficit) days between watering], with five replicates per treatment, totaling 60 seedlings.

The average soil moisture was evaluated according to the time interval of each water treatment with a Hidro Farm portable meter, HFM 2010 (Falker). The average volumetric soil moisture was 11.2, 5.6 and 4.3, respectively, for control, watering every five and ten days.

The vegetative growth was evaluated at the end of the experimental period (70 days), being determined the plant height $(\mathrm{cm})$, stem diameter $(\mathrm{mm})$ and the number of leaves (unt) and the dry matter production for the stem, leaves and roots (g) and the root /shoot ratio, the leaf area $\left(\mathrm{cm}^{2}\right)$ using the leaf contour method, the specific leaf area $\left(\mathrm{cm}^{2} . \mathrm{g} .{ }^{-1} . \mathrm{LDM}\right)$ and the leaf area ratio $\left(\mathrm{cm}^{2} . \mathrm{g} .{ }^{-1}\right.$.TDM), according to the methodology described by Benincasa (2003).

The height of the seedlings was measured with a ruler $(\mathrm{cm})$, measuring from the previously marked base until the 
insertion of the youngest leaf. The basal stem diameter $(\mathrm{mm})$ was measured with a digital caliper (Digimess) at the previously marked location. The plants were separated into leaves, stem and root, packed in paper bags and taken to a drying oven at $65^{\circ} \mathrm{C}$. After reaching constant weight, they were weighed on an analytical balance (Shimadzu AUY220) to determine the weight of root dry matter (RDM), stem dry matter (SDM) and leaf dry matter (LDM). With these results, the dry biomass partition for the different organs and the root / shoot ratio $(\mathrm{R} / \mathrm{S})$ were calculated. The leaf area was determined using the leaf contour method described by Benincasa (2003). For this, fresh leaves were collected and separated according to treatment and replication. Then, they were placed on A4 sheets with the identification, attached with a small piece of adhesive tape in the petiole region. Subsequently, the leaf outlines were printed on A4 papers of very homogeneous density (Premium INK, 75g / $\mathrm{m}^{2}$ paper), which were cut and weighed, comparing with the known areas of the same paper $\left(4 \mathrm{~cm}^{2}\right)$. Using the analytical balance, the weight of the leaf contours (WLC), the weight of the known area (WKA) and the known area of the leaf (KAL) were obtained. Using a simple rule of three, the leaf area (AF) was determined, as follows: LA = (WLC $x$ KAL) / WKA.

The germination parameters were calculated using the GerminaQuant 1.0 software (Marques et al. 2015). The data were tested for normality using the Shapiro-Wilk test. When parametric, data were submitted to double factor analysis of variance and the means compared by the Tukey test $(P<0.05)$, and the nonparametric ones were submitted to the KruskalWallis test and the means compared by the Dunn Post Doc test $(P<0.05)$ in Sigma Plot 12.0 software (Systat Software Inc, Germany). The dry matter data of the stem were transformed into a $\log$ for normalization, but the mean absolute values are being shown. The graphics were made using the software Sigma Plot 12.0 (Systat Software Inc, Germany).

\section{Results and Discussion}

\subsection{Germination}

The previous exposure of sugar apple seeds to the cycles of hydration and dehydration (HD) influenced the germinative parameters and the initial growth of seedlings of the species. Exposure to the three cycles of HD promoted an increase in germinability $(\% \mathrm{G})$ and emergence rate index (ERI), while reducing the mean germination time (MGT) (Table 1). There were no significant differences for the synchrony $(Z)$.

Table 1. Germinability (\%G), mean germination time (MGT), emergence rate index (ERI), and seed synchrony of germination (Z) of sugar apple (A. squamosa) seeds subjected to different hydration and dehydration cycles ( $0,1,2$ e 3 HD cycles).

\begin{tabular}{ccccc}
\hline HD Cycle & \%G & MGT $\left(\right.$ days $\left.^{-1}\right)$ & ERI & Z \\
\hline 0C & $21,5 \mathrm{~b}$ & $37,52 \mathrm{a}$ & $0,30 \mathrm{~b}$ & $0,027 \mathrm{a}$ \\
$\mathbf{1 C}$ & $16,5 \mathrm{~b}$ & $36,30 \mathrm{a}$ & $0,25 \mathrm{~b}$ & $0,090 \mathrm{a}$ \\
$\mathbf{2 C}$ & $10,0 \mathrm{~b}$ & $38,58 \mathrm{a}$ & $0,13 \mathrm{~b}$ & $0,150 \mathrm{a}$ \\
$\mathbf{3 C}$ & $52,5 \mathrm{a}$ & $33,41 \mathrm{~b}$ & $0,81 \mathrm{a}$ & $0,075 \mathrm{a}$ \\
\hline
\end{tabular}

Equal letters do not differ by Tukey's test $(P<0,05)$. Source: Authors.

These results suggest an improvement in the germination of sugar apple seeds when they are submitted to three cycles of HD. Although a percentage of $52.5 \%$ is considered low, these values represent an increase of $109 \%$ when compared to the control, demonstrating the benefits of discontinuous hydration for the species, since the literature reports a very low germinability for the sugar apple seeds (Menegazzo et al., 2012; Parmar et al., 2016).

A greater germination in less time it was observed after passing through three cycles of HD (Table 1). This improvement may be associated with increased seed vigor due to mitigation against damage to the plasma membrane (Bhadane 
et al., 2019). Another important point is the acceleration in the end of the pre-germinative metabolic activities and an increase in the physiological activity of the embryo caused by the physical-chemical changes that occur in the protoplasm stimulated by conditioning (Bhadane et al., 2019). Thus, cell division may have been accelerated and cell stretching improved (Bhadane et al., 2019; Samal et al., 2019).

The improvement in germination aspects has also been observed in other fruit trees when the seeds are submitted to other conditioning agents, such as soursop (Annona muricata L.), which showed maximum germination when treated with gibberellic acid $\left(\mathrm{GA}_{3}\right)$ and values between 65.8 to $91.6 \%$ using water, with germination close to $50 \%$ being observed for the control treatment (Singh \& Maheswari, 2017). It was also observed by Parmar et al. (2016) by conditioning sugar apple seeds with $\mathrm{GA}_{3} 200 \mathrm{mgL}^{-1}, 2 \%$ potassium nitrate $\left(\mathrm{KNO}_{3}\right)$ and thiourea, all for 12 hours, increasing seed germinability from $28 \%$ (when not conditioned) to 63, 46 and 50\%, respectively. In addition, Okoli et al. (2016) observed reductions in the mean time of emergence of soursop seedlings from hydroconditioned seeds, approximately 13 days before the control treatment.

\subsection{Initial growth and dry matter accumulation}

The initial growth of sugar apple seedlings, under the conditions studied, seems to be the result of the interplay between water availability and exposure to HD cycles in seeds (Table 2). Differential sensitivity to drought was observed between the different seedling organs. The plant height was little affected by the reduction of soil water content. However, exposure to HD cycles in seeds seems to have promoted an improved response to intermittent drought, as observed in seedlings grown with watering intervals every ten days (Table 2), which showed an increase of about $39 \%$ in height compared to those in the same water treatment from unconditioned seeds $(0 \mathrm{C})$. Under adequate water availability, the seedlings of that same cycle (3C) were approximately $40 \%$ higher than those of unconditioned seeds.

Although the height was little influenced by water deficiency, the stem diameter and the number of leaves showed greater sensitivity to drought, regardless of the HD cycle (Table 2). On the other hand, there is an increase in these parameters in seedlings from seeds that have undergone three cycles of $\mathrm{HD}$, even when watered every ten days. The seedlings of this treatment (3C) had a stem diameter $25 \%$ larger than seedlings of unconditioned seeds (0C) in the same watering interval, as well as an increase of $96 \%$ in relation to the number of leaves. It is important to note that seedlings from three cycles of HD in the seeds showed a greater number of leaves and stem diameter in all water treatments, when compared to those from unconditioned seeds (Table 2). The emission of new leaves, even under stress, allows the photosynthetic rates necessary for plant growth and metabolism to be properly maintained, enabling the adoption of mitigating strategies to this condition (Freitas \& Silva, 2018). 
Table 2. Plant height (H), stem diameter (SD), and number of leaves (NL) of sugar apple (A. squamosa) seedlings, produced by seeds submitted to different hydration and dehydration cycles $(0,1,2$ e 3 cycles $)$, that underwent intermittent drought.

\begin{tabular}{ccccc}
\hline HD cycle & $\begin{array}{c}\text { Water } \\
\text { treatment }\end{array}$ & H (cm) & SD (mm) & NL (un) \\
\hline \multirow{2}{*}{$\mathbf{0 C}$} & $\mathbf{C}$ & $12,57 \mathrm{aB}$ & $3,35 \mathrm{aB}$ & $12,25 \mathrm{aB}$ \\
& $\mathbf{E 5}$ & $12,4 \mathrm{aA}$ & $2,83 \mathrm{aB}$ & $8,32 \mathrm{bB}$ \\
& $\mathbf{1 0}$ & $9,95 \mathrm{aB}$ & $2,2 \mathrm{bB}$ & $6,25 \mathrm{bB}$ \\
\hline \multirow{2}{*}{$\mathbf{1 C}$} & $\mathbf{C}$ & $13,82 \mathrm{abAB}$ & $3,32 \mathrm{aB}$ & $12,5 \mathrm{aB}$ \\
& $\mathbf{E 5}$ & $17,12 \mathrm{aA}$ & $3,42 \mathrm{aAB}$ & $11,75 \mathrm{aAB}$ \\
& $\mathbf{1 0}$ & $10,75 \mathrm{bAB}$ & $2,47 \mathrm{aA}$ & $7,75 \mathrm{bB}$ \\
\hline \multirow{2}{*}{$\mathbf{2 C}$} & $\mathbf{C}$ & $16,57 \mathrm{aA}$ & $3,90 \mathrm{aAB}$ & $15 \mathrm{aB}$ \\
& $\mathbf{E 5}$ & $12,4 \mathrm{bA}$ & $2,92 \mathrm{bAB}$ & $9,25 \mathrm{bAB}$ \\
& $\mathbf{1 0}$ & $11,72 \mathrm{bAB}$ & $2,6 \mathrm{bA}$ & $8,25 \mathrm{bB}$ \\
\hline \multirow{2}{*}{$\mathbf{3 C}$} & $\mathbf{C}$ & $17,75 \mathrm{aA}$ & $4,20 \mathrm{aA}$ & $18,5 \mathrm{aA}$ \\
& $\mathbf{E 5}$ & $17 \mathrm{aA}$ & $3,75 \mathrm{aA}$ & $14,0 \mathrm{abA}$ \\
& $\mathbf{1 0}$ & $13,85 \mathrm{aA}$ & $2,75 \mathrm{bA}$ & $12,25 \mathrm{bA}$ \\
\hline
\end{tabular}

Equal letters (lower-case compare the differences between water treatments within each HD cycle and upper-case compare the same water treatment in different HD cycles) do not differ by Tukey's test at $5 \%$ probability $(P<0,05)$. Source: Authors.

These results are similar to those observed by Okoli et al. (2016) and Singh \& Maheswari (2017) who found higher growth rates in soursop seedlings (Annona muricata L.) from seeds that underwent hydration and dehydration, or when seeds were hydrated in different periods, from 12 to 72 hours, without subsequent dehydration. The same was observed by Parmar et al. (2016) evaluating sugar apple seeds with other conditioning agents, such as $\mathrm{GA}_{3}, \mathrm{KNO}_{3}$ and thiourea, showing that, regardless of the nature of the conditioning agent, when properly used, it has the ability to promote improvement in the aspects of initial seedling growth.

In addition, under water stress, seedlings from conditioned seeds may have continued growth due to the tolerance promoted by conditioning, through previously initiated metabolic processes, such as prolonged protein synthesis during germination, expressed in the future (Trigo \& Trigo, 1999), or due to the redistribution of nutrient reserves, stimulating an increase in cell division (Samal et al., 2019). In addition, they may have increased the rate of absorption of water and nutrients available from seedlings (Bhadane et al., 2019) resulting in greater growth.

The accumulation of dry matter in the leaves of sugar apple seedlings was not influenced by intermittent drought or HD cycles in seeds (Table 3). On the other hand, reductions in the production of dry matter from the stem and root were noticed when the seedlings were submitted to intervals of ten days between irrigations, reflecting the production of total dry matter. The accumulation of dry matter from the stem in seedlings from seeds that have undergone three cycles of HD has doubled in relation to those obtained from unconditioned seeds, in all water treatments. Although the water deficit reduced the dry matter of these organs when watered every ten days (Table 3), the seedlings watered every five days managed to keep the stem and root dry matter values close to the control treatment, suggesting an attenuation of the effects of water deficiency in seedlings obtained from seeds that experienced three cycles of HD. No significant results were found for the root/shoot ratio. 
Table 3. Leaf dry matter (LDM), stem dry matter (SDM), root dry matter (RDM), total dry matter (TDM) and root/shoot ratio (R/S) of sugar apple (A. squamosa) seedlings, produced by seeds submitted to different hydration and dehydration cycles $(0,1$, 2 e 3 cycles), that underwent intermittent drought.

\begin{tabular}{ccccc}
\hline LDM (g) & SDM (g) & RDM (g) & TDM (g) & R/S (g) \\
\hline $0,32 \mathrm{aA}$ & $0,14 \mathrm{aB}$ & $0,42 \mathrm{aB}$ & $0,89 \mathrm{aB}$ & $0,84 \mathrm{aA}$ \\
$0,24 \mathrm{aA}$ & $0,09 \mathrm{abB}$ & $0,26 \mathrm{aB}$ & $0,60 \mathrm{aB}$ & $2,19 \mathrm{aA}$ \\
$0,22 \mathrm{aA}$ & $0,06 \mathrm{bB}$ & $0,34 \mathrm{aA}$ & $0,63 \mathrm{aA}$ & $1,18 \mathrm{aA}$ \\
\hline $0,41 \mathrm{aA}$ & $0,17 \mathrm{aAB}$ & $0,60 \mathrm{aAB}$ & $1,19 \mathrm{aAB}$ & $1,05 \mathrm{aA}$ \\
$0,46 \mathrm{aA}$ & $0,16 \mathrm{aAB}$ & $0,46 \mathrm{abAB}$ & $1,09 \mathrm{abAB}$ & $0,72 \mathrm{bA}$ \\
$0,20 \mathrm{aA}$ & $0,08 \mathrm{aAB}$ & $0,26 \mathrm{bA}$ & $0,55 \mathrm{bA}$ & $1,36 \mathrm{abA}$ \\
\hline
\end{tabular}

Equal lower-case letters compare the differences between water treatments within each HD cycle and upper-case letters compare the same water treatment in different HD cycles, do not differ by Tukey's test at 5\% probability. $(P<0,05)$. Source: Authors.

In this perspective, seedlings from conditioned seeds can have, under stressful conditions, significant accumulation of biomass (Hussian et al., 2013; Jisha et al., 2016; Bhadane et al., 2019). This increase in dry matter may occur due to the use of lipids by the glyoxalate cycle, a primitive pathway that leads to faster growth of seedlings, allowing them to produce a relatively larger amount of dry matter (Bhadane et al., 2019), as well as the prolonged synthesis of proteins during the germination expressed during the growth (Trigo \& Trigo, 1999). The results can also be related to a better photosynthetic capacity of the seedlings, even under stressful conditions (Jisha \& Puthur, 2016), although carbon metabolism has not been evaluated in this work.

Similar results were observed by Parmar et al. (2016) with sugar apple seedlings obtained from seeds conditioned to $\mathrm{GA}_{3}, \mathrm{KNO}_{3}$ and thiourea. In addition, Menegazoo et al. (2012) also found that the root and shoot dry matter increased due to the conditioning of seeds to $\mathrm{GA}_{3}$. Similarly, in some crops, the increase in the production of dry matter under a stressful situation, originating from hydroconditioned seeds, has been demonstrated by some authors for rice (Hussian et al., 2013), chickpeas (Samal et al. (2019) and mung beans (Bradhane et al., 2019), which supports and resembles the findings found here.

The leaf area of the seedlings was reduced due to water deprivation, especially when watered every ten days, however, these effects were mitigated by the application of three cycles of HD in the seeds (Table 4). There was an increase in leaf area in all water treatments for seedlings from the three cycles of HD in seeds compared to those obtained from unconditioned seeds. In this same perspective, seedlings watered every five and ten days, obtained from seeds that have undergone three cycles of HD, showed a greater specific leaf area compared to the other cycles (Table 4), despite the drought having little influence on it and the leaf area ratio. Expressive results were not observed for leaf area ratio, only an increase in leaflet originating from the three cycles of HD in seeds compared to unconditioned ones, when watered every ten days (Table 4). 
Table 4. Leaf area (LA), Specific leaf area (SLA) and Leaf area ratio (LAR) of sugar apple (A. squamosa) seedlings, produced by seeds submitted to differents hydration and dehydration cycles ( $0,1,2$ e 3 cycles), that underwent intermittent drought.

\begin{tabular}{ccccc}
\hline HD cycle & Water treatment & LA $\left(\mathrm{cm}^{2}\right)$ & SLA $\left(\mathrm{cm}^{2} \cdot \mathrm{g} \cdot{ }^{-1} \cdot \mathrm{LDM}\right)$ & LAR $\left(\mathrm{cm}^{2} \cdot \mathrm{g} \cdot{ }^{-1} \cdot \mathrm{TDM}\right)$ \\
\hline \multirow{2}{*}{$\mathbf{0 C}$} & $\mathbf{C}$ & $68,89 \mathrm{aB}$ & $179,51 \mathrm{aA}$ & $64,92 \mathrm{abA}$ \\
& $\mathbf{E 5}$ & $54,87 \mathrm{aB}$ & $146,24 \mathrm{aB}$ & $69,29 \mathrm{Aa}$ \\
& $\mathbf{1 0}$ & $25,35 \mathrm{bB}$ & $117,80 \mathrm{bB}$ & $40,45 \mathrm{bB}$ \\
\hline \multirow{2}{*}{$\mathbf{1 C}$} & $\mathbf{C}$ & $72,83 \mathrm{abAB}$ & $193,65 \mathrm{aA}$ & $67,94 \mathrm{aA}$ \\
& $\mathbf{E 5}$ & $90,90 \mathrm{aAB}$ & $156,45 \mathrm{aB}$ & $67,60 \mathrm{aA}$ \\
& $\mathbf{1 0}$ & $29,59 \mathrm{bAB}$ & $103,95 \mathrm{aB}$ & $42,85 \mathrm{aAB}$ \\
\hline \multirow{2}{*}{$\mathbf{2 C}$} & $\mathbf{C}$ & $111,30 \mathrm{aAB}$ & $198,73 \mathrm{aA}$ & $78,35 \mathrm{aA}$ \\
& $\mathbf{E 5}$ & $47,47 \mathrm{bB}$ & $145,14 \mathrm{aB}$ & $53,41 \mathrm{aA}$ \\
& $\mathbf{1 0}$ & $42,87 \mathrm{bAB}$ & $170,85 \mathrm{aAB}$ & $65,32 \mathrm{aAB}$ \\
\hline \multirow{2}{*}{$\mathbf{3 C}$} & $\mathbf{C}$ & $126,90 \mathrm{aA}$ & $191,88 \mathrm{aA}$ & $64,43 \mathrm{aA}$ \\
& $\mathbf{E 5}$ & $113,20 \mathrm{abA}$ & $244,85 \mathrm{aA}$ & $74,13 \mathrm{aA}$ \\
& $\mathbf{1 0}$ & $59,49 \mathrm{bA}$ & $239,07 \mathrm{aA}$ & $71,80 \mathrm{aA}$ \\
\hline
\end{tabular}

Equal lower-case letters compare the differences between water treatments within each HD cycle and upper-case letters compare the same water treatment in different HD cycles, do not differ by Tukey's test at $5 \%$ probability. $(P<0,05)$. Source: Authors.

This increase in leaf area under water deprivation (Table 4) may have occurred due to increased cell division and elongation, as well as a higher photosynthetic rate, even during drought, because leaves from conditioned seed plants tend to have more starch (Samal et al., 2019). In this logic, Okoli et al. (2016) observed that soursop seedlings, from hydroconditioned seeds, doubled their leaf area when compared to those obtained from unconditioned seeds, which has also been observed for agricultural crops (Jisha \& Puthur 2016; Bhadane et al. 2019; Samal et al. 2019). In addition, considering that the leaf area is the basis of the yield of a crop, this larger leaf area and specific leaf area may have enabled greater $\mathrm{CO}_{2}$ uptake and assimilation, promoting greater growth (Table 2) and production of dry biomass (Table 3).

These results demonstrate the action that promotes conditioning by hardening the germinative parameters and growth rhythms, even under intermittent drought, suggesting that applying hydration and dehydration cycles to the sugar apple seeds during pre-germination contributes to stimulating the stress memory, promoting a greater acquisition of drought tolerance.

\section{Conclusion}

The application of three cycles of HD in the seeds as a pre-germinative treatment improves the germinative parameters and benefits the initial growth and drought tolerance of sugar apple seedlings.

Sugar apple seeds have memory of stress, which allows for accelerated germination and the production of seedlings under conditions of water deprivation in the soil, and a water regime of irrigation can be applied at five-day intervals, without significant morphophysiological changes.

For a better understanding of the effects of HD cycles on drought tolerance in sugar apple, research evaluating different times of hydration and dehydration in seeds, as well as enzymatic responses in the formation of reactive oxygen species are required and proposed for future research.

\section{Acknowledgments}


The authors thank the Coordenação de Pesquisa (COPES) of the Universidade Federal de Sergipe for the scholarship of the first and second author; and to the staff of Plant Physiology and Ecophysiology Laboratory of the Universidade Federal de Sergipe for the support in conducting the experiment.

\section{References}

Benincasa, M. M. P. (2003). Análise de crescimento de plantas: noções básicas. (2a ed.), Funep. 41p.

Bhadane, R. S., Prajapati, K. R., Patel, D. B. (2019). Effect of seed hardening on morpho-physiological characters in Mung bean (Vigna radiata L.). International Journal of Chemical Studies, 7(4), 1760-1763.

Chen, K. \& Arora, R. (2013) Priming memory invokes seed stress-tolerance. Environ. Exp. Bot., 94, 33-45. 10.1016/j.envexpbot.2012.03.005

Farooq, M., Usman, M., Nadeem, F., Rehman, H., Wahid, A., Basra, S. M. A., \& Siddique, K. H. M. (2018). Seed priming in field crops: potential benefits, adoption and challenges. Crop and Pasture Science, 70(9), 731-771. 10.1071/CP18604

Freitas, R. S. \& Silva, E. C. (2018). Respostas fisiológicas de mudas de Aspidosperma pyrifollium (Apocynaceae) à ciclos de suspensão de rega. Scientia Plena, 14(5), 1-12. 10.14808/sci.plena.2018.051201

Güneralp, B., Güneralp, I., \& Liu, Y. (2015). Changing global patterns of urban exposure to flood and drought hazards. Global environmental change, 31, 217-225. 10.1016/j.gloenvcha.2015.01.002

Hussian, I., Ahmad, R., Farooq, M., Rehman, A., \& Amin, M. (2013). Seed priming improves the performance of poor quality wheat seed under drought stress. Appl. Sci. Rep., 7, 12-18.

Jisha, K. C., \& Puthur, J. T. (2016). Seed priming with beta-amino butyric acid improves abiotic stress tolerance in rice seedlings. Rice Sci, 23(5), 242-254. 10.1016/j.rsci.2016.08.002

Lemos, E. E. P. (2014). The production of Annona fruits in Brazil. Revista Brasileira de Fruticultura, 36(1), 77-85. 10.1590/S0100-29452014000500009

Li, Y., Ye, W., Wang, M., Yang, X. (2009). Climate change and drought: a risk assessment of crop-yield impacts. Clim. Res., 39, 31-46. doi.org/10.3354/cr00797

Lima, A. T., Cunha, P. H. de J., Dantas, B. F., \& Meiado, M. V. (2018). Does discontinuous hydration of Senna spectabilis (DC.) H.S. Irwin \& Barneby var. excelsa (Schrad.) H.S. Irwin \& Barneby (Fabaceae) seeds confer tolerance to water stress during seed germination?. Journal of Seed Sciences (antiga Revista Brasileira de Sementes), 40, 36-43. 10.1590/2317-1545v40n1182838

Mahajan, G., Sarlach, R. S., Japinder, S., \& Gill, M. S. (2011). Seed Priming Effects on Germination, Growth and Yield of Dry Direct-Seeded Rice. Journal of Crop Improvement, 25(4), 409-417. 10.1080/15427528.2011.576381

Marengo, J. A., Cunha, A. P., \& Alves, L. M. (2016). A seca de 2012-15 no semiárido do Nordeste do Brasil no contexto histórico. Revista Climanálise, 3, 4954.

Marques, F. R. F., Meiado, M.V., Castro, N. M. C. R., Campos, M. L. O., Mendes, K. R., Santos, O. O., \& Pompelli, M. F. (2015). GerminaQuant : a new tool for germination measurements. J. Seed Sci., 37, 248-255. 10.1590/2317-1545v37n3145605

Meiado, M. V. (2013). Evidências de memória hídrica em sementes da Caatinga. In 64 Congresso Nacional de Botânica: botânica sempre viva. Belo Horizonte, 2013. Anais. Belo Horizonte, Sociedade Botânica do Brasil, p.83-94.

Menegazzo, M. L., Oliveira, A. C., Kulczynski, S. M., \& Silva, E. A. (2012). Efeitos de métodos de superação de dormência em sementes de pinha (Annona squamosa L.). Agrarian, 5(15), 29-35, 2012.

Okoli, N. A, Obiefuna, J. C., Alagba, R. A., \& Emma-Okafor, L.C. (2016). Improvement of germination and seedling vigour of soursop (Annona muricata L.) using hydro-priming and dehydration treatments. FUTOJNLS, 2, 56-61, 2016.

Oliveira Júnior, L. F. G., Santos, P. L. S., Lima, R. S. N., Silveira, M. P. C., Fagundes, J. L., Carnelossi, M. A. G., \& Reis, F. O. (2019). Physiological parameters of cowpea treated with CaO-based particle film and subjected to water restriction. Pesquisa Agropecuária Brasileira, 54, e00033. 10.1590/S16783921.pab2019.v54.00033.

Parmar, R. K., Patel, M. J., Thakkar, R. M., \& Tsomu, T. (2016). Influence of seed priming treatments on germination and seedling vigour of custard apple (Annona squamosa L.) cv. local. The Bioscar, 11(1), 389-393.

Ramos, Y. C., Mourão Filho, F. A. A., Stuchi, E. S., Sentelhas, P. C., \& Fadel, A. L. (2016). Sensibilidade de laranjeiras-doces ao déficit hídrico. Pesq. agropec. bras., 51(1), 86-89. 10.1590/S0100-204X2016000100011

Rodrigues, B. M., Souza, B. D., Nogueira, R. M., \& Santos, M. G. (2010). Tolerance to water deficit in young trees of jackfruit and sugar apple. Revista Ciência Agronômica, 41(2), 245-252. doi.org/10.1590/S1806-66902010000200011

Samal, J. A., Bhadane, R. S., \& Patel, D. B. (2019). Influence of seed hardening on growth and yield of chickpea var. GG-2 (Cicer arietinum L.). International Journal of Chemical Studies, 7(4), 1756-159.

Santos Júnior, J. L., Oliveira, M. F. C., \& Silva, E. C. (2020). Acúmulo de solutos orgânicos em mudas de Ceiba glaziovii (Kutze) Kum. em resposta à seca intermitente. Scientia Plena, 16 (1). 1, 011201. doi.org/10.14808/sci.plena.2020.011201 
Research, Society and Development, v. 10, n. 3, e56710313706, 2021

(CC BY 4.0) | ISSN 2525-3409 | DOI: http://dx.doi.org/10.33448/rsd-v10i3.13706

Silva, E. C., Albuquerque, M. B., Azevedo Neto, A. D., \& Silva Junior, C. D. (2013). Drought and its consequences to plants from individual to ecosystem. In: Sener Akinci, editor. Responses of organisms to water stress. Croatia: InTech. 17-47. 10.5772/53833

Singh, S. J., \& Maheswari, T. U. (2017). Influence of pre-sowing seed treatments on the performance of soursop (Annona muricata L.) seedlings. Plant Archives, 17(2), 1215-1218.

Sousa, S. A., Dantas, A. C. V. L., Pelacani, C. R., Vieira, E. L., \& Ledo, C. A. S. (2008). Superação da dormência em sementes de pinha. Revista Caatinga, 21(4), 118-121.

Trigo, M. F. O. O., \& Trigo, L. F. N. (1999). Efeito do condicionamento na germinação e no vigor de sementes de berinjela (Solanum melongena L.). Revista Brasileira de Sementes, 21(1), 107-113.

Wojtyla, L., Paluch-Lubawa, E., Sobieszczuk-Nowicka, E., \& Garnczarska, M. (2020). Drought stress memory and subsequent drought stress tolerance in plants. In: Priming-Mediated Stress and Cross-Stress Tolerance in Crop Plants. Academic Press, 115-131.

Xu, L., Chen, N., \& Zhang, X. (2019). Global drought trends under 1.5 and $2^{\circ}$ C warming. International Journal of Climatology, 39(4), 2375-2385. doi.org/10.1002/joc.5958 